\title{
MARKETING ON THE CONSTRUCTION MARKET IN A ECONOMIC CRISIS
}

\author{
Dinu Cristina ${ }^{1}$
}

\begin{abstract}
Construction market has a tremendous impact on our national economy. What happens in the construction industry reflects society's demands, both from a perspective of demographic trends and especially of the financing. The current economic slowdown requires to review the way marketing is done. The companies must eliminate unaccountable marketing programs and actions that generate insufficient sales leads and fail to support the sales team efforts. The marketing can be done in a better way.
\end{abstract}

Key words: marketing, economic crisis, construction market, direct marketing

JEL Code: M31

\section{Introduction}

On the construction market you will come across more often than before to a dynamic and better informed involvement from the project beneficiary (final client). Nowadays' beneficiary is the one who have the control over the money to be invested, therefore he defines the project according with the terms that desires. Then he looks for the necessary expertise to carry out the project.

To satisfy demand from the residential sector, commercial and industrial sectors, the construction industry needs to change. Some entrepreneurs will look at this step with confidence, as a solution generating exciting new opportunity while others will make mistakes for fear of the unknown. The businessman's reactions to the changes is which will lead him to a market full of opportunities for the company's favor, or the disappearance of the market.

Construction industry offers to designers, architecture, engineering but also for marketers, the chance of exciting professional challenges and many different ways to build a career. But lately, there is a need for people that work in this market to change their perceptions in order to cope with the current business environment. They need more flexibility in thinking and ingenuity in the strategies discussed. "The work is planned and plans are achieved through work " - is true but sometimes work is not enough. It feels the need of a "spark" or an idea, a new approach (maybe) that make the company more visible to potential customers and win loyalty of existing clients. "To succeed, must first believe that we can succeed" said Michael Korda.

\section{Characteristics of the construction market}

Before developing some aspects of construction market we need to define some specific terms:

* Beneficiary / client is a person which/who owns the project to be build

* General Contractor (or general builder) is the company which provide manpower and managerial skills needed to execute the project.

*Construction Project Manager has competent staff necessary to prepare feasibility studies as well as administrative and executive experience in terms of subcontracting by subcontractors.

\footnotetext{
${ }^{1}$ Spiru Haret University, Bucharest, Email: dinu.cristina@gmail.com
} 
*The architect or a design engineer conduct technical design documentation for construction of the objective in question.

* Subcontractors is the provider providing services in a particular category of works.

The difference between a main contractor and subcontractor is on such a contractual relationship: general contractor receives the contract directly from the beneficiary, while subcontractors contracting with the project manager.

*The final product is the purpose built.

Construction manager or general contractor works on two core markets: the public market and private market. There are great differences in terms of processes that general contractors, project managers and subcontractors must comply for bidding on these two very different markets. In the public domain, anyone interested should strictly according to tender documents and specifications issued by the competent authority. In the public auctions, construction works are attributed to builders or project managers by a single law: the one who comes with the lowest price wins. This applies both to the architect and the main contractor, project manager and the subcontractors. Public procurement are not paid to think, but to submit a bid with the specifications. Therefore, there is no need for too much marketing. Firms of this type, carefully monitors the sources in announcing and awarding tenders for public works projects, such as Official Monitor, specialized web site (www.e-licitatii.ro, etc..), mayor's websites, specialized publications, etc..

Private market is on the opposite side, there is a close cooperation between all parties involved: the beneficiary, designer, builder. The beneficiary know what type of building wishes to build and both the architect and the constructor gives him several options and solutions for the desired comfort. The private sector is composed of several categories: commercial spaces for private operators (for example commercial buildings), spaces for rent (for example an office building, hotels), industrial buildings (for example halls), objective educational (schools, kindergartens), institutions and places of worship (churches, chapels, etc.).

Within the construction companies, (usually small), the function of marketing and sales that are combined in a single department. Most construction companies do not have any financial strength nor the personnel needed to set up two separate departments.

Basically, marketing staff works with statistical data on various types of construction markets by developing lists of potential customers for other groups of staff from the company who sell construction services or products. Often, in charge of marketing activity is one and same as in charge of business development. It happens quite often that when businesses begin to stagnate or while decreases the number of customers and revenues are also adversely affected the owner or manager to be engage in strategic planning and marketing process problems. These are signs that have taken some measures and plans are needed.

Strategic planning is a fundamental component of economic activity, but most employers do not find time to ensure the prosperity of their businesses. When businesses drop, the managers are aware of the importance of the strategic plan but when things go well (on the spur overall market growth), the plan is totally ignored. Marketing plan (as a component of strategic planning) must have marketing objectives and results to be pursued and a final goal, which indicate where the company will be more than one year, two, is a plan with concrete measures to enforce.

(Too) Many construction companies prepare their marketing plans vague, with no set deadlines and without practical issues. When turnover is heading into an unwanted direction, company executives are interested in what it was done or not. They say: 'We' contracts! We need more contracts! but does not review what goes wrong and what is to do further.

\section{Current economic context}

In 2008, According to the "Construction sector in Romania 2009 - Development forecasts for 2009-2011", 3 rd edition, an report published by PMR in 2008 (PMR press releases, (2009), “A challenging year ahead for Romanian construction", available on-line at 
http://www.pmrpublications.com/press_room/en_A-challenging-year-ahead-for-Romanianconstruction.shtml), the value of construction and assembly works in Romania increased by $34 \%$ nominally ( $26 \%$ in real terms). The fastest growing segment was non-residential, which increased by $37 \%$. The situation is due to the fact that Romania, a country with a very rapidly developing economy, needed mainly non-residential buildings, such as office space for services and industrial buildings. Structural works are by far the ones covering the largest share of costs of a construction project, followed by installation and equipment and site preparations. The smallest shares are held by finishings and rental of construction equipment.

However, the problems on the international financial markets affected the national construction industry. Robert Obetkon, a senior construction market analyst at PMR says that : "The most affected year will be 2009 , but the following few years may not see a major recovery if the international economic circumstances do not improve. The construction sector will, however, be supported by the spending of EU funds allocated for Romania, which will be directed mainly into infrastructure." (PRLog (Press Release) - Apr 22, 2009, "Construction sector in Romania 2009" available on-line at http://www.prlog.org/10222009-construction-sector-in-romania-2009.html). Non-residential construction, which used to be the fastest growing segment of the Romanian construction market, seems to be most affected, because of its overdependence on credit (some developers launched before ensuring their financing) to which is added the decrease in demand for these buildings. Only those of which construction works were already begun before Q4 2008 will be completed in 2009.

The present situation of residential construction in Romania has been determined by the property market. After two years of constantly growing demand which powered the rising prices of homes, the residential property market started to contract in Q4 2008. This was mainly the result of the fact that banks have been unwilling to grant mortgage loans to the population. Similarly, developers are facing crediting difficulties and therefore in 2009 only a few projects will be delivered, generally those which were either delayed from last year or are in an advanced construction state.

The economic climate in the Romania forced most business owners to step up their marketing efforts as well as reduce their expenses. Therefore, businesses owners will need to review how they are creating value for their customers. Budgets for marketing will be reduced and companies will look for more cost-effective ways to reach their target audiences. Maybe being more innovative is the key to attract customers to your products.

\section{How you advertise during crisis}

Some companies are quick to cut their marketing budgets in an effort to cut costs in the wake of an unforeseeable future. I think the exact opposite is necessary. Reducing marketing budgets in times of crisis, despite innovative marketing being the most efficient solution to weather through a slowdown is a big mistake. History has shown that companies which implemented efficient marketing strategies during crises, tend to grow in times of economic recovery. On the contrary, companies which reduce their marketing budgets during such periods do our company can surv not exceed a growth rate of 17 per cent. Adapting does in no way mean cutting your budget for actions that generate more sales. How does anyone expect sales numbers to stay constant or to increase, if they tear apart their advertising campaigns?

A means solution would be migration from expensive traditional advertising to online marketing and direct marketing because advertisers are able to measure instant returns from small investments, which they can then scale up if they work well.

The Internet is a means of communication that marketing cant ignore because of it's advantages: the Internet offers possibilities to smartly communicate to a target group in a sophisticated and interactive way, far away from pure advertising language, and trustable and true for the recipient, Online Marketing is a clear alternative to the traditional methods of advertising, is 
a universal source of information . The costs to market products on the Internet are much lower than conventional means and may help the retailer to reduce costs in view of the lower profits that are expected. So, many companies will be going to the Internet in an attempt to market their products. This means the construction companies will have to learn such things as how to design a website, how to write a blog, how to participate in the social networks and how to conduct e-mail marketing. Each company needs to find the tools which will be most useful for their business.

Many on-line marketers are making use of blogs and videos to promote themselves and their companies. Blogs offer a way to reveal more information about the company or its products without giving a sales pitch but I don't think that is the most suitable for construction market. Most consumers on the construction market trust the opinion of friends or specialists (even strangers) when it comes to choosing products for construction. That is why, online communities like blogs or forums don't have a great success in our country (on construction segment). If you type the name of a hotel into Google, you'll find fewer or more comments by people who stayed recently and you will find them more reliable than the claims on the hotel's own website. But what will you find typing on Google a name of a constructor or a building materials providers? A list of providers and their websites and some online catalogs. There are still many construction companies that have no website. Some of them can be found online catalogs.

The Internet is the ideal medium for direct marketing development because it allows direct and accurate targeting marketing messages to specific individuals, especially individuals who were identified and characterized on the basis of their behavior on the Internet. It offers the real possibility of implementation of marketing techniques individually (one - to - one marketing). Involving users in the transactional process is greatly increased, because they can choose promotional messages or information they wish to access. Getting an instant feedback from users, is extremely effective in providing services to services with direct effects on consumer loyalty.

Why should we turn to direct marketing in the construction marketing during crisis?

1. Because direct marketing is targeted. Targeting means to achieve a very well-defined target segment and send them personalized messages. This involves:

- defining the target by using socio-demographic, economic and financial indicators(income, gender, age, environment: rural / urban, etc.-if the beneficiary is a person, turnover, number of staff, profit type of work performed, etc. if the company sales to a company ( activates in a business to business market)

- test the various categories of potential consumers / customers

- customize the message according to characteristics of the target

2. Because direct marketing is interactive. Direct marketing initiates a dialogue between the seller (the vendor) and buyer (or potential customer). Interaction is achieved through the fulfillment of two conditions: establishing a means of response to the target: call, enter the site, send SMS, complete a questionnaire, comes at one place, buy, etc.. and use of a stimulus (offer, customizing the message, personal visit) to get a reaction.

3. Direct marketing is measurable. At the end of direct marketing campaign you will know exactly how much money has been invested and how much money has been recovered by analyzing the efficiency indicators

. 4. Direct marketing is aimed at cost. It will be very easy at the end of the campaign to calculate profitability.

5. For direct marketing can be tested. Unlike classical advertising, direct marketing can be tested. Testing consists in achieving one or more monitor-programs to promote proper implementation. After testing to draw some conclusions and based on their campaign directly marketign results will be higher. Thus, much of the budget that could be invested wrong is saved. 
6. Direct marketing builds loyalty. As practice has shown many times, winning a customer can cost ten times more than his preservation. Customers are a permanent source of reference and continuous sales, they will pay more when you consider that the services / products worth using detailed database specialists can adapt their offer to the specific needs of each client and communicate with him personally.

7. Direct marketing is easy to "hid". Direct marketing can take any form: a phone, a brochure, a person who comes directly to potential customers, a mail, a TV show, a radio spot, etc.. The more creative the more results will be higher.

8. Direct marketing uses a variety of channels of communication: from advertising by mail, magazines, newspapers, telephone, TV, radio, Internet and more recently, mobile phone.

\section{Conclusions}

Consumers have curtailed their spending and because of that are seeking bargains more than ever. So, they will not be spending the exorbitant amounts of money they were accustomed to spending in the past. In a crisis people buy brands they know and trust because they what not to spend their money on something that doesn't last. Even though there is less money flowing in the economy, customers still need products. The companies will need to go back to the basics of selling and hone up on your skills and in the same time, must learn new ways of marketing their products in a way which will attract customers to their business. People buy because of the value they perceive in products. Therefore, the companies must help their prospect to see value in buying their products. The clients must also feel confident about the company's ability to resolve their problem.

People are still going to buy what they need and want badly enough, they just need to find your product/service and company before they find your competitor's. That is why, the need that a company to be "omnipresent" is greater than it has ever been before. In time like this of uncertainty, the company must market more aggressively, and in the same time, manage costs effectively.

Unlike other industries, building industry comes with a unique specific feature, that companies need to sell "products" through relationships established with recipients. The effort to obtain lucrative contracts is a collective, not individual. The work of construction companies was, is and will always be founded on direct relationships, face to face with customers. In other economic branches can happen that sales representatives of some companies do not have to meet customers face to face - but not in the building industry. Regardless of financial instruments and technologies, construction industry will remain "a world of concrete and glass", an area that is concrete, tangible.

\section{References:}

1. Pryor P., 2005. Marketingul serviciilor de construcţii, Codecs Publishing House, Romania, Bucureşti.

2. Stone B., Jacobs R., 2000. Metode de succes în marketingul direct, ARC Publishing House, România, Bucureşti.

3. Vegheş C., 2003. Marketing Direct, Uranus Publishing House, România, Bucureşti.

4. www.pmrpublications.com

5. www.prlog.org

6. http://marketingpr.suite101.com

7. www.globalchange.com 